\title{
TINJAUAN YURIDIS TERHADAP PAJAK PENGHASILAN ATAS USAHA JASA KONSTRUKSI
}

\author{
Oleh: \\ Muhammad Yasid ${ }^{1)}$, \\ Hang Bun ${ }^{2)}$, \\ Universitas Darma Agung, Medan. 1), 2) \\ E-mail: \\ $\frac{\text { yasidfakultashukum@gmail.com }}{{ }^{1} \text { budi_sempurna@yahoo.com }}{ }^{2}$,
}

\begin{abstract}
Taxes are a very important source of state revenue for administering government and implementing national development. So that the Government places taxation obligations as one of the manifestations of state obligations which are a means of financing the state in national development in order to achieve the goals of the State. This research uses a normative method, which is to analyze problems and research through an approach in statutory regulations and also from books, papers, laws and other references. The construction service business is a tax object subject to final Income Tax (PPh) of Article 4 paragraph (2). In the construction service business, the construction service contractor or entrepreneur is subject to tax. This applies to both those who have and who do not have certification and qualifications as professionals in the construction sector in accordance with the provisions stipulated in the Construction Services Development Agency (LPJK) Regulation Number 11 of 2006. The legal umbrella governing taxes on construction service businesses is listed in Government Regulation (PP) Number 51 of 2008 as amended by Government Regulation Number 40 of 2009 concerning Income Tax on Income from Construction Services Business (hereinafter referred to as PP 51/2008 stdd PP 40/2009).
\end{abstract}

Keywords: income tax, construction business

\begin{abstract}
ABSTRAK
Pajak merupakan sumber pendapatan Negara yang sangat penting bagi penyelenggara pemerintahan dan pelaksanaan pembangunan nasional. Sehingga Pemerintah menempatkan kewajiban perpajakan sebagai salah satu perwujudan kewajiban kenegaraan yang merupakan sarana dalam pembiayaan negara dalam pembangunan nasional guna tercapainya tujuan Negara. Penelitian ini menggunakan metode normatif, yaitu melakukan analisis terhadap permasalahan dan penelitian melalui pendekatan dalam peraturan perundang-undangan dan juga bersumber dari bukubuku, makalah, undang-undang dan referensi lainnya. Usaha jasa konstruksi
\end{abstract}


merupakan objek pajak yang dikenakan Pajak Penghasilan (PPh) Pasal 4 ayat (2) yang bersifat final. Dalam kegiatan usaha jasa konstruksi, kontraktor atau pengusaha jasa konstruksi menjadi subjek pajak. Hal ini berlaku baik bagi yang sudah maupun yang belum memiliki sertifikasi dan kualifikasi sebagai profesional dalam bidang konstruksi sesuai dengan ketentuan yang diatur dalam peraturan Lembaga Pengembangan Jasa Konstruksi (LPJK) Nomor 11 Tahun 2006. Payung hukum yang mengatur tentang pajak atas usaha jasa konstruksi tercantum dalam Peraturan Pemerintah (PP) Nomor 51 Tahun 2008 sebagaimana telah diubah dengan PP Nomor 40 tahun 2009 tentang Pajak Penghasilan atas Penghasilan dari Usaha Jasa Konstruksi (selanjutnya disebut PP 51/2008 stdd PP 40/2009).

\section{Kata Kunci : Pajak Penghasilan, Usaha konstruksi}

\section{PENDAHULUAN}

Pajak merupakan sumber pendapatan Negara yang sangat penting bagi penyelenggara pemerintahan dan pelaksanaan pembangunan nasional. Sehingga Pemerintah menempatkan kewajiban perpajakan sebagai salah satu perwujudan kewajiban kenegaraan yang merupakan sarana dalam pembiayaan negara dalam pembangunan nasional guna tercapainya tujuan Negara."

Industri Jasa Konstruksi di Indonesia mulai diatur secara komperhensif, pasca reformasi politik di Indonesia, melalui Undang- Undang RI Nomor 18 Tahun 1999 tentang Jasa Konstruksi. Selanjutnya, terbit Peraturan Pemerintah terkait tentang Jasa Konstruksi, yaitu Peraturan Pemerintah RI Nomor 28 Tahun 2000 tentang Usaha dan Peran Masyarakat Jasa Konstruksi, Peraturan Pemerintah RI Nomor 29 Tahun 2000 tentang Penyelenggaraan Jasa Konstruksi, Peraturan Pemerintah RI Nomor 30 Tahun 2000 tentang Penyelenggaraan Pembinaan Jasa Konstruksi. Berkaitan dengan penghasilan yang dikategorikan sebagai objek pajak. Undang- undang RI Nomor 36 Tahun
2008 tentang Pajak Penghasilan, Pasal 4 ayat (1) menyebutkan bahwa :

Pengaturan mengenai pengenaan Pajak atas jasa usaha konstruksi juga diatur dalam Pasal 23 ayat (1) huruf c angka 2 UU PPh:

atas penghasilan tersebut di bawah ini dengan nama dan dalam bentuk apapun yang dibayarkan, disediakan untuk dibayarkan, atau telah jatuh tempo pembayarannya oleh badan pemerintah, subjek pajak badan dalam negeri, penyelenggaraan kegiatan, bentuk usaha tetap, atau perwakilan perusahaan luar negeri lainnya kepada Wajib Pajak dalam negeri atau bentuk usaha tetap, dipotong pajak oleh pihak yang wajib membayarkan sebesar $2 \%$ (dua persen) dari jumlah bruto atas imbalan sehubungan dengan jasa teknik, jasa majemen, jasa konstruksi, jasa konsultan, dan jasa lain selain jasa yang telah dipotong Pajak Penghasilan sebagaimana dimaksud dalam Pasal 21.

\section{TINJAUAN PUSTAKA}

Pengertian pajak penghasilan adalah pajak yang dikenakan terhadap subyek pajak atas penghasilan yang diterima atau diperolehnya dalam tahun pajak. Dasar hukum pengenaan 
pajak penghasilan adalah Undang Undang Nomor 7 Tahun 1983 tentang Pajak Penghasilan sebagaimana telah diubah terakhir dengan Undang Undang Nomor 36 Tahun 2008 yang selanjutnya disebut Undang-Undang Pajak Penghasilan (UU PPh).

Yang dapat dijadikan objek pajak sangat banyak macamnya. Segala sesuatu yang ada dalam masyarakat dapat dijadikan sasaran atau objek pajak baik keadaan, perbuatan maupun peristiwa, misalnya

a. Keadaan, kekayaan seseorang pada suatu saat tertentu memiliki kendaraan bermotor, radio, televisi, memiliki tanah atau barang tidak bergerak, rumah tertentu (kebanyakan secara statis/tetap).

b. Perbuatan melakukan penyerapan barang karena perjanjian, mendirikan rumah atau gedung, mengadakan pertunjukkan atau keramaian, memperoleh penghasilan, berpergian ke luar negeri.

c. Peristiwa kematian, keuntungan yang diperoleh secara mendadak, anugerah yang diperoleh karena secara tak terduga, pokoknya segala sesuatu yang terjadi diluar kehendak manusia.

Dilihat dari mengalirnya tambahan kemampuan ekonomi kepada wajib pajak, penghasilan dapat dikelompokkan menjadi :

1. Penghasilan dari pekerjaan dalam hubungan kerja dan pekerjaan bebas.

2. Penghasilan dari usaha dan kegiatan

3. Penghasilan dari modal

4. Penghasilan lain-lain.
Menurut pasal 2 ayat (2) UU PPh subyek pajak dibedakan menjadi subyek pajak dalam negeri dan subyek pajak luar negeri. Yang dimasuksud dengan subyek pajak dalam negeri adalah:

1. Orang pribadi yang bertempat tinggal di Indonesia atau orang pribadi yang berada di Indonesia lebih dari 183 (seratus delapan puluh tiga) hari dalam jangka waktu 12 (dua belas) bulan, ataupun pribadi yang dalam suatu tahun pajak berada di Indonesia dan mempunyai niat untuk bertempat tinggal di Indonesia

2. Badan yang didirikan atau bertempat kedudukan di Indonesia

3. Warisan yang belum terbagi sebagai suatu kesatuan, menggantikan yang berhak.

Secara teoritis dikenal sebagai macam tarif pajak yang dapat diterapkan, yaitu
a. Tarif tetap
b. Tarif
proporsional (sebanding/sepadan)
c. Tarif progresif (presentase meningkat)
d. Tarif degresif (presentase menurun)

\section{METODE PENELITIAN}

Penelitian ini merupakan suatu penelitian hukum normative yang dilakukan untuk mencari masalah atau isu hukum dan permasalahan hukum yang ada. Hasil dari penelitian hukum ini adalah memberikan preskripsi mengenai apa yang ada mengenai isu hukum yang diajukan. Sifat Penelitian ini adalah deskriptif, sumber yang digunakan adalah data primer, data sekunder dan bahan non-hukum. Data 
primer yang dimaksud dalam bentuk Undang-Undang Dasar Negara Republik Indonesia Nomor 16 Tahun 2009 tentang Penetapan Peraturan Pemerintah Pengganti Undang-Undang Nomor 5 Tahun 2008 tentang Perubahan Keempat Atas UndangUndang Nomor 6 Tahun 1983 tentang Ketentuan Umum Dan Tata Cara Perpajakan Menjadi Undang-Undang, Undang- Undang nomor 36 Tahun 2008 tentang Perubahan Keempat Atas Undang-Undang Nomor 7 Tahun 2983 tentang Pajak Penghasilan.

Data sekunder berupa semua publikasi tentang hukum yang bukan merupakan dokumen-dokumen resmi. Publikasi tentang hukum meliputi buku-buku teks, kamus-kamus hukum, jurnal-jurnal hukum, dan komentarkomentar atas putusan pengadilan.

Teknik pengumpulan data dengan cara studi kepustakaan. Pendekatan yang digunakan dalam penelitian hukum ini adalah:

a. Pendekatan perundang-undangan (statue approach), diperlukan guna mengkaji lebih lanjut mengenai landasan hukum dengan menelaah undang-undang dan regulasi yag bersangkut paut dengan isu hukum yang sedang ditangani yaitu mengenai "analisis hukum pajak terhadap pajak penghasilan atas usaha jasa konstruksi".

b. Pendekatan konseptual (conceptual approach) yaitu beranjak dari pandanganpandangan dan doktrin-doktrin yang berkembang di dalam ilmu hukum. Peneliti akan menemukan ide-ide yang melahirkan pengertian-pengertian hukum, konsep-konsep hukum dan asas- asas hukum yang relevan dengan isu yang dihadapi.

Analisa yang digunakan lebih banyak kepada pola pikir (paragdigma) yang diteliti dengan pendekatan teoriteori yang dipakai. Begitu isu hukum ditetapkan, perlu dilakukan penelusuran untuk mencari bahanbahan hukum yang relavan terhadap isu yang dihadapi. Bahan hukum primer dan bahan hukum sekunder yang telah dikumpulkan tersebut kemudian dikelompokkan dan dikaji berdasarkan pendekatan yang digunakan. Dalam penelitian ini, yang digunakan adalah pendekatan konseptual, pendekatan perundangundangan, dan pendekatan perbandingan untuk memperoleh gambaran yang sistematis dan komperehensif dari badan hukum primer dan sekunder yang diperoleh untuk menghasilkan preskripsi atau argumentasi hukum yang baru.

\section{HASIL PEMBAHASAN}

DAN

\section{A. Pengaturan Tentang Pemotongan Pajak Penghasilan Usaha Jasa Konstruksi}

Berdasarkan UU KUP Nomor 28 Tahun 2007, Pasal 1 ayat (1) pengertian Pajak adalah kontribusi wajib kepada negara yang terutang oleh orang pribadi atau badan yang bersifat memaksa berdasarkan undangundang, dengan tidak mendapatkan imbalan secara langsung dan digunakan untuk keperluan negara bagi sebesar-besarnya kemakmuran rakyat. Sebelum UU KUP Nomor 28 Tahun 2007 diberlakukan, ada beberapa dasar hukum perpajakan 
yang pernah berlaku dan masih berlaku di Indonesia, yaitu:

a. Undang-Undang Dasar Republik Indonesia 1945 Dalam naskah asli UUD 1945 Pasal 23 ayat (2), mengatur "segala pajak untuk keperluan negara berdasarkan UU, sedangkan berdasarkan amandemen termuat Pasal 23A "Pajak dan pungutan lain yang bersifat memaksa untuk keperluan negara diatur dengan UU'.

b. Undang-Undang Nomor 6 Tahun 1983 tentang Ketentuan Umum dan Tata Cara Perpajakan Pasal 1 angka 1 tentang KUP adalah kontribusi wajib kepada negara yang terutang oleh orang pribadi atau badan yang bersifat memaksa berdasarkan Undang-Undang, dengan tidak mendapat timbal balik secara langsung dan digunakan untuk keperluan negara bagi kemakmuran rakyat.

c. Undang-Undang Nomor 19 Tahun 1997 tentang Penagihan Pajak dengan Surat Paksa Berdasarkan pasal 1, Pajak ialah semua jenis pajak yang dipungut oleh Pemerintah Pusat, termasuk Bea Masuk dan Cukai, dan pajak yang dipungut oleh Pemerintah Daerah, menurut undang-undang dan peraturan daerah.

d. Undang-Undang Nomor 16 Tahun 2000 tentang Perubahan Atas Undang-Undang Nomor 6 Tahun 1983 tentang Ketentuan Umum dan Tata Cara Perpajakan Pasal 12 ayat 1-3 menerangkan bahwa setiap wajib pajak yang membayar pajak yang terutang berdasarkan ketentuan perundangundangan perpajakan, dengan tidak menggantungkan pada adanya surat ketetapan pajak.

e. Undang-Undang Nomor 18 Tahun 2000 tentang Perubahan Kedua Atas Undang-Undang Nomor 8 Tahun 1983 tentang Pajak Pertambahan Nilai Barang dan Jasa dan Pajak dan Pajak Penjualan Atas Barang Mewah Dalam pasal 1 ayat dijelaskan bahwa setiap wajib pajak wajib melaporkan data terkait nilai kekayaan dan barang mewah yang dimilikinya.

f. Undang-Undang Nomor 17 Tahun 2000 tentang tentang Perubahan Ketiga Atas Undang-Undang Nomor 7 Tahun 1983 Pajak Penghasilan Pasal 3 diterangkan bahwa kewajiban pajak subjektif orang pribadi atau badan sebagaimana dimaksud dalam pasal 2 ayat (4) dimulai pada saat orang pribadi atau orang tersebut menjalankan usahanya dan berakhir apabila tidak lagi menjalankan usahanya.

g. Undang-Undang Nomor 19 Tahun 2000 tentang Perubahan Atas Undang-Undang Nomor 19 Tahun 1997 tentang Penagihan Pajak Dengan Surat Paksa Terdapat dalam pasal 1 ayat 2 yaitu penagihan pajak dapat berjalan secara pararel dengan proses permohonan keberatan atau banding oleh wajib pajak.

h. Undang-Undang Nomor 14 Tahun 2002 tentang Pengadilan Pajak Dalam pasal 1 ayat 1 dikatakan sengketa pajak ialah sengketa yang timbul dalam bidang perpajakan atau penanggung pajak dengan pejabat yang berwenang sebagai akibat dikeluarkannya 
keputusan yang dapat diajukan banding atau gugatan kepada pengadilan pajak berdasarkan peraturan perundang-undangan.

i. Undang-Undang Nomor 28 Tahun 2007 tentang Perubahan Ketiga Atas Undang-Undang Nomor 6 Tahun 1983 tentang Ketentuan Umum dan Tata Cara Perpajakan Pasal 2 ayat(1) yaitu semua wajib pajak yang telah memenuhi persyaratan subjektif sesuai dengan ketentuan peraturan perundang-undang perpajakan berdasarkan sistem self assesment, wajib pajak mendaftarkan diri pada kantor Direktorat Jenderal Pajak dan sekaligus untuk mendapatkan Nomor Pokok Wajib Pajak (NPWP).

j. Undang-Undang Nomor 36 Tahun 2008 tentang Perubahan Keempat Atas Undang-Undang Nomor 7 Tahun 1983 tentang Pajak Penghasilan Pasal 2 ayat (1) yang menjadi subjek pajak adalah orang pribadi, warisan yang belum terbagi sebagai suatu kesatuan menggantikan yang berlaku, badan, dan bentuk usaha tetap (BUT).

Dasar Pengenaan PPh Pasal 4 Ayat 2 atas Jasa Konstruksi. adalah sebagai berikut:

1. Jika dipotong oleh pemotong pajak dalam hal ini bendahara pemotong yaitu jumlah pembayaran (tidak termasuk PPN).

2. Jika penyedia jasa menyetor sendiri dalam hal ini perusahaan jasa konstruksi, dasar pengenaan pajaknya yaitu jumlah penerimaan pembayaran (tidak termasuk PPN).
Tarif PPh Pasal 4 ayat 2 atas Jasa Konstruksi. Tarif yang dikenakan untuk pajak penghasilan atas usaha jasa konstruksi ini berbedabeda, dilihat menurut kepemilikan sertifikat badan usaha dan masa berlakunya sertifikat tersebut. Untuk jasa pelaksana konstruksi, tarifnya ditentukan berdasarkan tingkatan dari kewenangan kontraktor. Tarif pajak penghasilan final pasal 4 ayat 2 atas jasa konstruksi yaitu sebesar 4\% untuk jasa perencanaan konstruksi apabila seorang kontraktor memiliki sertifikat badan usaha, dan $6 \%$ bagi kontraktor yang tidak memiliki sertifikat badan usaha.

Untuk jasa pelaksanaan konstruksi apabila kontraktor tersebut memiliki sertifikat badan usaha dan masuk dalam kategori usaha kecil (tingkatan 1,2,3,4) maka dikenakan tarif sebesar $2 \%$, sedangkan untuk kontraktor yang memiliki sertifikat badan usaha yang masuk dalam kategori usaha menengah dan besar (tingkatan 5,6,7) dan kontraktor tersebut tidak memiliki sertifikat badan usaha maka tarif yang dikenakan yaitu sebesar 4\%. Untuk jasa pengawasan konstruksi dikenakan tarif $4 \%$ bagi kontraktor yang memiliki sertifikat badan usaha dan $6 \%$ bagi kontraktor yang tidak memiliki sertifikat badan usaha.

Atas penghasilan dari usaha Jasa Konstruksi dikenakan Pajak Penghasilan yang bersifat final. Adapun Tarif Pajak Penghasilan yang bersifat final: 
a. $2 \%$ (dua persen) untuk Pelaksanaan Konstruksi yang dilakukan oleh Penyedia Jasa dengan kualifikasi usaha kecil

b. $4 \%$ (empat persen) untuk Pelaksanaan Konstruksi yang dilakukan oleh Penyedia Jasa yang tidak memiliki kualifikasi usaha.

c. $3 \%$ (tiga persen) untuk Pelaksanaan Konstruksi yang dilakukan oleh Penyedia Jasa selain Penyedia Jasa sebagaimana dimaksud dalam huruf a dan huruf $b$

d. $4 \%$ (empat persen) untuk Perencanaan Konstruksi atau Pengawasan Konstruksi yang dilakukan oleh Penyedia Jasa yang memiliki kualifikasi usaha

e. $6 \%$ (enam persen) untuk Perencanaan Konstruksi atau Pengawasan Konstruksi yang dilakukan oleh Penyedia Jasa yang tidak memiliki kualifikasi usaha. Jurnal Bisnis Terapan Volume 01, Nomor 02, Desember $201759 \quad$ Pajak penghasilan yang pengenaannya bersifat Final mengacu pada Pasal 4 ayat (2) Undang-Undang Pajak Penghasilan sebagai penghasilan tertentu yang pengenaan pajaknya diatur dalam peraturan pemerintah.

\section{B. Penerapan Pemotongan Pajak Penghasilan Usaha Jasa Konstruksi}

Dalam praktek, banyak pemotong pajak mengalami kesulitan dalam membedakan jasa konstruksi yang diatur dalam pasal 4 ayat (2) dan jasa konstruksi yang diatur dalam Pasal 23 UU Pajak Penghasilan. Untuk dapat membedakan antara keduanya maka pemahaman terhadap kriteria jasa konstruksi yang menjadi objek pemotongan Pasal 23 harus dibatasi pada jenis jasa yang tercantum dalam Pasal 1 ayat (2) Peraturan Menteri Keuangan nomor 244 tahun 2008 yang dilakukan oleh Wajib Pajak yang tidak mempunyai klasifikasi sebagai pengusaha jasa konstruksi.

Berkenaan dengan pemotongan pajak penghasilan, dalam pasal 23 ayat (1) huruf c angka 2 diatur bahwa atas penghasilan tersebut di bawah ini dengan nama dan dalam bentuk apa pun yang dibayarkan, disediakan untuk dibayarkan, atau telah jatuh tempo pembayarannya oleh badan pemerintah, subjek pajak badan dalam negeri, penyelenggara kegiatan, bentuk usaha tetap, atau perwakilan perusahaan luar negeri lainnya kepada Wajib Pajak dalam negeri atau bentuk usaha tetap, dipotong pajak oleh pihak yang wajib membayarkan sebesar $2 \%$ (dua persen) dari jumlah bruto atas imbalan sehubungan dengan jasa teknik, jasa manajemen, jasa konstruksi, jasa konsultan, dan jasa lain selain jasa yang telah dipotong Pajak Penghasilan sebagaimana dimaksud dalam Pasal 21.

Contoh penerapan pemotongan pajak konstriksi yaitu Ibu Susi berencana membangun rumah di kawasan Mampang, Jakarta Selatan. Untuk keperluan tersebut, dia mendatangi perusahaan konstruksi. Meski perusahaan konstruksi ini masih terbilang kecil namun Ibu Susi ingin mempercayakan pengerjaan rumahnya ke perusahaan tersebut. Dia mengkonsultasikan semuanya. Mulai dari perencanaan, tata letak bangunan, ukuran ruangan, pemilihan bahan 
bangunan sampai target pengerjaan. Setelah berdiskusi panjang lebar, akhirnya kedua belah pihak sepakat untuk bekerjasama.

Perusahaan konstruksi ini kemudian memberikan dokumen yang di dalamnya terdapat rincian biaya yang dibutuhkan. Nah, rincian biaya inilah disebut dengan nilai kontrak. Dengan beberapa kali pertemuan dan pertimbangan, akhirnya rician biaya disetujui di atas materai dengan nilai kontrak Rp. 2 miliar. Ibu Susi kemudian menyetujui dengan syarat semua biaya akan dibayar lunas saat pengerjaan selesai. kontrak ini disimpan kedua belah pihak sebagai tanda bukti.

Setelah pengerjaan rumah selesai, Ibu Susi menepati janjinya dengan membayar nilai kontrak sebesar Rp. 2 miliar. Karena penyedia jasa konstruksi adalah perusahaan yang memiliki kualifikasi usaha kecil, maka dikenakan tarif 3\% sehingga perhitungannya akan seperti ini : Nilai kontrak X Tarif PPh Jasa Konstruksi yaitu Rp. 2 miliar x $3 \%=\mathrm{Rp}$. 60.000.000. Dengan demikian, PPh Jasa Konstruksi yang harus disetor ke kas Negara adalah Rp. 60 juta. Jumlah uang yang sudah dihitung sebagai Pajak Penghasilan Jasa Konstruksi harus dipotong dari nilai kontrak, lalu disetorkan dan dilaporkan dalam masa pajak yang sama yaitu maksimal tanggal 15 setelah pelunasan pembayaran.

Setelah Ibu Susi menyetor pajak tersebut dan melaporkannya, perusahaan konstruksi itu akan mendapatkan buki potong $\mathrm{PPh}$ atas jasa konstuksi yang diberikan oleh Ibu Susi. Kemudian buki potong tersebut akan dilaporkan pada akhir tahun pelaporan pajak sebagai pajak final dalam Surat Pemberitahuan Tahunan (SPT) Pajak perusahaan konstruksi tersebut.

\section{Hambatan-Hambatan Yang Dihadapi Dalam Penerapan Pemotongan Pajak Penghasilan Usaha Jasa Konstruksi}

Meskipun pemungutan pajak secara teoritik maupun secara hukum memiliki dasar yang kuat, namun daalm praktek pemungutannya ada banyak hambatan yang mungkin terjadi. Ada setidaknya dua jenis hambatan dalam pemungutan pajak :

1. Adanya perlawanan pasif

Perlawanan pasif yang dilakukan bisa berupa keengganan wajib pajak membayar pajak. Keengganan ini dipicu oleh beberapa alasan misalnya perkembangan intelektual dan moral wajib pajak. Kurangnya edukasi terkait pajak membuat masyarakat kurang menyadari arti pentingnya membayar pajak, sehingga mereka enggan membayar pajak. Demikian pula pengelolaan pajak, maraknya korupsi, penegakan hukum yang lemah memberikan perkembangan kurang baik bagi pertumbuhan kesadaran masyarakat untuk membayar pajak. Alasan lain keenganan membayar pajak adalah karena sistem perpajakan yang cenderung sulit dan rumit, sehingga masyarakat kurang dapat memahami tata laksanan perpajakan. Mereka akan berpendapat mau bayar saja kok rumit. Alasan lainnya lagi adalah sistem kontrol yang tidak jalan. Mereka yang tidak membayar pajak ternyata tidak mendapat sangsi. Hal ini akan menimbulkan pemikiran untuk 
apa membayar pajak kalau tidak ada sangsi bila tidak membayar.

2. Adanya pelawanan aktif

Perlawanan aktif ini memiliki dua bentuk. Bentuk pertama disebut tax avoidance. Istilah untuk menyebut upaya-upaya menghindari pajak tanpa melanggar hukum. Bentuk yang kedua adalah tax evasion. Merupakan upaya menghindari pajak dengan cara-cara melanggar hukum atau ilegal.

Mencermati perkembangan jumlah pelaku usaha dan asosiasi yang terus bertambah dengan motif yang jauh dari nilai profesionalisme, maka pemerintah diharapkan dapat melahirkan kebijakan yang menjadikan proses validasi asosiasi yang menyelenggarakan sertifikasi, serta meningkatkan pelaku jasa konstruksi untuk mengedepankan profesionalitas serta menjadi sarana melahirkan pelaku usaha dengan daya saing tinggi.

1. Tidak jelasnya Penanggung jawab sektor konstruksi. Tidak jelasnya Penanggung jawab sektor konstruksi ini dapat dilihat bahwa perintah Menteri Dalam Negeri untuk membentuk Tim Analisa dan Evaluasi Hukum Tentang Jasa Konstruksi BPHN Pembina Jasa Konstruksi diseluruh Indonesia melalui surat edaran No. 601/476/SJ tanggal 13 Maret 2006 tidak kunjung selesai. Saat ini dari 33 Propinsi dan 476 Kabupaten/Kota yang baru mendirikan ada 30 Provinsi dan kurang lebih 150 Kabupaten/Kota .Itupun sekedar mendirikan dan tidak melakukan operasional, padahal Menteri Dalam Negeri sudah memberikan petunjuk agar disediakan juga dana pembinaan jasa konstruksi disetiap daerah. Disisi lain perintah Peraturan Pemerintah No. 28 Tahun 2000 pasal 14 bahwa dibuat Peraturan Daerah untuk menerbitkan Izin Usaha Jasa Konstruksi ternyata juga tidak dipatuhi dan dilaksanakan oleh pemerintah daerah. Banyak Izin Usaha Jasa Konstruksi tidak dibuat melalui Perda tapi cukup Surat Keputusan Kepala Daerah dimasing-masing daerah dan banyak yang beranggapan Izin Usaha Jasa Konstruksi adalah Pendapatan Asli Daerah dan oleh sebab itu sering biaya IUJK cukup tinggi. Kewajiban setiap pemerintah daerah untuk memberikan Laporan ke Menteri Pekerjaan Umum, sebagaimana diatur dalam Peraturan Menteri Permukiman dan Prasarana Wilayah No. 369/KPTS/M/2001 tidak pernah dipatuhi, sehingga kalau ditanya IUJK di seluruh Indonesia ini maka tidak ada yang bisa menjawab. Departemen Pekerjaan Umum juga belum merasa bahwa pekerjaan konstruksi menjadi tanggung jawabnya hal ini terlihat jelas saat Peraturan Menteri No. 43 tahun 2007 tentang "Standar Dokumen Pelelangan Nasional" dikeluarkan, dimana dalam buku tersebut tertulis jelas mengacu pada Peraturan Pemerintah No. 29 tahun 2008 dan sifatnya nasional namun hanya berlaku di lingkungan Departemen Pekerjaan Umum serta pula hanya dana APBN, sehingga sulit diterapkan pada jasa konstruksi di pemerintah daerah propinsi maupun kabupaten/kota yang sumber 
dananya APBD. Baru-baru ini Menteri Pekerjaan Umum juga mengeluarkan Sistem Manajemen Keselamatan dan Kesehatan melalui Peraturan Menteri Nomor 09/PRT/M/2008 tentang Pedoman Sistem Manajemen Analisa dan Evaluasi Hukum Tentang Jasa Konstruksi BPHN Keselamatan dan Kesehatan Kerja (K3) Konstruksi Bidang Pekerjaan Umum, namun inipun hanya berlaku di lingkungan Departemen Pekerjaan Umum bahkan muncul bidang baru yakni yang disebut bidang pekerjaan umum. Dan masih banyak yang sifatnya rancu dan sulit diterapkan yang menyebabkan timbulnya persoalan di daerah.

2. Arah Pengembangan Jasa Konstruksi Jauh dari Upaya Peningkatan Profesionalisme. Keberadaan UU No 18 Tahun 1999 tentang Jasa Konstruksi yang ditujukan untuk meningkatkan profesionalisme pelaku usaha di sektor jasa konstruksi melalui peningkatan peran masyarakat jasa konstruksi, masih jauh dari harapan. Dari pengaturan yang tidak konsisten dan keberadaan institusi yang kurang Departemen Pekerjaan Umum hanya mengurusi jalan, sumber daya air dan ciptakarya serta tata ruang, sedangkan jasa konstruksi tidak dianggap significant. Berbagai tindakan persaingan usaha tidak sehat dalam sektor itu bermunculan yang diindikasikan adanya Keputusan dari Komisi Pengawasan Persaingan Usaha yang menetapkan beberapa perkara persaingan usaha tidak sehat di sektor jasa konstruksi, yang hampir seluruhnya muncul dalam bentuk persekongkolan lelang. Jauhnya pengembangan jasa konstruksi dari upaya peningkatan profesionalisme, lebih banyak disebabkan terdistorsinya pengaturan sektor tersebut oleh kepentingan pihakpihak tertentu yang selama ini memegang peran penting dalam sektor jasa konstruksi. Hal inilah yang menyebabkan permasalahan di sektor jasa konstruksi terus bermunculan.

3. Kurang profesionalnya pejabat pengadaan jasa konstruksi. Jika dilihat kondisi di pemerintah daerah propinsi dan kabupaten/kota maka akan terlihat bahwa para petugas pengadaan jasa konstruksi ini masih sangat lemah dalam menguasai aturan pengadaan. Analisa dan Evaluasi Hukum Tentang Jasa Konstruksi BPHN Umumnya menganggap aturan pengadaan bisa dijalankan asal sudah sesuai dalam Keputusan Presiden tentang pengadaan barang/jasa pemerintah tanpa perlu memahami makna yang terkandung didalamnya, padahal kita menghadapi persoalan hukum, contoh konkrite adalah sering para panitia lelang menerima dokumen yang sudah direkayasa oleh penyedia jasa, namun karena sulitnya untuk mencari kebenaran atau referensi sumber data maka dibuatlah seakan-akan dokumen tersebut asli, dengan dibubuhi keterangan sesuai aslinya dan dimintakan pihak ketiga yang melakukan 
legalisasi seperti Asosiasi atau LPJK.

4. Dominasi Peran Unsur Pelaku Usaha dalam Lembaga Pengembangan Jasa Konstruksi (LPJK) Dari pengamatan dapat ditemukan fakta bahwa salah satu penyebab terbesar dari terdistorsinya pelaksanaan UU No. 18 Tahun 1999 adalah sangat dominannya unsur pelaku usaha yang diwakili asosiasi perusahaan jasa konstruksi dalam LPJK yang memiliki peran strategis dalam pengembangan sektor jasa konstruksi. Penelitian di lapangan memperlihatkan bahwa unsur pelaku usaha sangat aktif dan mendominasi peran dalam LPJK. Akibat dari kondisi ini maka tidak mengherankan apabila perkembangan LPJK banyak terdistorsi oleh kepentingan pelaku usaha melalui perannya di Lembaga. Bahkan dalam perkembangannya, LPJK sering menjadi sumber dari lahirnya perilaku persaingan usaha tidak sehat. Distorsi semakin menjadijadi, setelah asosiasi juga diberi kewenangan melakukan sertifikasi.

5. Potensi Persaingan Usaha Tidak Sehat Dalam Industri Jasa Konstruksi Berdasarkan pengamatan, teridentifikasi beberapa potensi persaingan usaha tidak sehat yang disebabkan oleh distorsi implementasi Undang Undang Nomor 18 Tahun 1999. Beberapa potensi persaingan usaha tidak sehat tersebut adalah:

6. Penunjukan perusahaan jasa konstruksi yang selalu direkayasa, diskriminasi terhadap pesaing melalui penyalahgunaan kewenangan panitia lelang dalam melakukan pengadaan.

Cara Mengatasi Hambatan Pajak:

1. Memberikan koordinasi terhadap lembaga terkait agar kondisi harta wajib pajak/penanggung pajak terdata dengan baik

2. Lebih tegas dalam pemungutannya seperti pemblokiran rekening penanggung pajak yang memiliki tunggakan pajak berlebih

3. Meningkatkan penggalangan jaringan kerja baik dari desa sampai pusat

4. Memberikan peningkatan pada penyuluhan kepada wajib pajak mengenai hak dan kewajiban yang mereka dapat

5. Keteraturan dari pelaksanaan dan pengorganisasian lebih terjaga dengan baik

\section{SIMPULAN}

Adapun kesimpulan yang diapat dari penelitian ini:

1. Pengaturan pemotongan pajak penghasilan Jasa Konstruksi diatur dalam Pasal 4 ayat (2) UU PPh yang bersifat final, hanya diterapkan bila usaha jasa konstruksi dari lembaga-lembaga pengembangan jasa konstruksi dimana dengan adanya sertifikat tersebut menjadikan wajib pajak pada usaha jasa konstruksi dikenakan pajak yang bersifat final dan yang tidak bersertifikat badan usaha dikenakan pajak tidak final yaitu Pasal 23 ayat (1) huruf c angka $2 \mathrm{PPh}$. 
2. Dalam penerapan Pajak Pasal 23 ayat (1) huruf c angka 2 pada usaha jasa konstruksi dilakukan dengan cara membuat ID billing terlebih dahulu, lalu membayarnya melalui Bank Persepsi ATM, teller bank, fitur bayar pajak online di Online Pajak yang telah disetujui oleh Kementerian Keuangan. Jatuh tempo pembayaran adalah tanggal 10, sebulan setelah bulan terutang pajak penghasilan. Sebagai tanda bahwa PPh Pasal 23 ayat (1) huruf c angka 2 telah dipotong, pihak pemotong harus memberikan bukti potong (rangkap 1) yang sudah dilengkapi kepada pihak yang dikenakan pajak tersebut dan bukti potong (rangkap ke 2) pada saat melakukan e-Filing pajak PPh Pasal 23 ayat (1) huruf c angka 2 di online pajak. Setelah itu Pelaporan dilakukan oleh pihak pemotong dengan cara mengisi

SPT Masa PPh Pasal 23, lalu bisa melaporkannya, melaui fitur lapor pajak online atau efilling gratis di Online Pajak. Jatuh tempo pelaporan adalah tanggal 20, sebulan setelah bulan terutang pajak penghasilan.

3. Hambatan yang dihadapi dalam pemotongan pajak penghasilan usaha jasa konstruksi, seringkali masyarakat kurang menyadari arti pentingnya membayar pajak,sehingga mereka enggan membayar pajak. Demikian pula pengelolaan pajak, maraknya korupsi, penegakan hukum yang lemah memberikan perkembangan kurang baik bagi pertumbuhan kesadaran masyarakat untuk membayar pajak

\section{DAFTAR PUSTAKA}

A. Buku-Buku

Bohari. 2004. Pengantar Hukum Pajak. Jakarta: Raja Grafindon Persada

Gunadi, Kebijakan Fiskal Untuk Meningkatkan Produktivitas Nasional, Universitas Indonesia, Jakarta

Hutomo, Sigit. 2018. Pajak Penghasilan. Yogyakarta: Andi Judisseno, Rimsky. 2004. Perpajakan. Jakarta: Gramedia Pustaka Utama

. 2004. Pajak dan Strategi Bisnis; Suatu Tinjauan tentang Kepastian Hukum dan Penerapan Akuntansi di Indonesia, Gramedia Pustaka Utama

Mulyono, Djoko. 2010. Hukum Pajak, Konsep, Aplikasi, dan Penuntun Praktis, Yotyakarta: Andi Offset

Pudyatmoko, Sri. 2002. Pengantar Hukum Pajak. Yogyakarta: Andi

Saidi, Muhammad Djafar. 2011. Pembaruan Hukum Pajak. Jakarta: Raja Grafindo

2011. Perlindungan Hukum Wajib Pajak dalam Penyelesaian Sengketa Pajak. Jakarta: Rajawali Pers

Sudarto. 2011. Meningkatkan Kinerja Perusahaan Jasa Konstruksi Di Indonesia. Jakarta: CSIS

Suparnyo, 2012. Hukum Pajak Suatu Sketsa Asas, Cetakan Ketiga, Pustaka Magister, Semarang. 
Supriyanto, Edy. 2014. Hukum Pajak Indonesia. Yogyakarta: Graha Ilmu

Sutedi, Andrian. 2008. Hukum Pajak dan Retribusi Daerah. Bogor: Graha Indonesia

Waluyo. 2006. Perpajakan Indonesia. Jakarta: Salemba Empat

\section{B. Perundang-undangan}

Undang Undang Nomor 7 Tahun 1983 tentang Pajak Penghasilan

Undang Undang Nomor 36 Tahun 2008 tentang Perubahan Keempat Atas Undang Undang Nomor 7 Tahun 1983 Tentang Pajak Penghasilan

Peraturan Pemerintah Nomor 51 Tahun 2008 tentang Pajak Penghasilan Atas Penghasilan Dari Usaha Jasa Konstruksi

Peraturan Pemerintah Nomor 40 Tahun 2009 tentang Perubahan atas Peraturan Pemerintah Nomor 51 tahun 2008 tentang Pajak Penghasilan Atas Penghasilan dari Usaha Jasa Konstruksi.

Peraturan Menteri Keuangan nomor 244/PMK.03/2008 tentang Jenis Jasa Lain Sebagaimana Dimaksud Dalam Pasal 23 Ayat (1) huruf c Angka 2

Undang-Undang Nomor 7 Tahun 1983 tentang Pajak Penghasilan Sebagaimana Telah Beberapa Kali Diubah Terakhir Dengan Undang-Undang Nomor 36 Tahun 2008 